\title{
Missionaries and Commanders: The Jesuits in Mindanao, 1718-68
}

\author{
Eberhard Crailsheim \\ CSIC - Instituto de Historia, Madrid, Spain \\ eberhard.crailsheim@cchs.csic.es
}

\begin{abstract}
In the Philippines, at the fringes of the Spanish empire, the Society of Jesus took on a difficult task, the mission and pastoral work on the Island of Mindanao, which was ruled mostly by Muslim polities. In the frontier zone between Spanish and Islamic spheres of influence, Jesuit missionaries, in symbiosis with Spanish and native Christian troops, tried to expand their zone of influence and force Islam back. Thereby, the priests participated actively in defensive and offensive military tasks. This article gives an overview of the Jesuits' presence in the south of the Philippines and then, by studying printed Jesuit sources, analyzes the image cultivation of the local members of the order. Putting the topic in the context of the anti-Jesuit discussion in Europe, the article reasons that the communication strategy of the Jesuits in the middle of the eighteenth century was particularly aimed at highlighting the usefulness of the missionaries to the colony and the empire in general.
\end{abstract}

\section{Keywords}

The Philippines - Jesuits - Spanish empire - Islam - eighteenth century communication - war - Mindanao - Sulu - missionaries

In 1718 , the Spaniards returned to their military strongholds in Mindanao, in the southern Philippines, they had been forced to abandon in 1663. Together with the soldiers, also the missionaries of the Society of Jesuit came back, eager to re-establish their missions. The following fifty years represented a dynamic 
succession of events in Mindanao and Sulu, in which the Jesuits played a remarkable role, torn between their global missionary endeavor and the need to locally protect their devouts. By analyzing chronicles and booklets of the eighteenth century, this study, first, depicts the specific Philippine setting and reflects on the prospects of proselytization among Muslims. Then, it gives a picture of the role of the Jesuit missionaries in Mindanao and presents some outstanding episodes of their activities. Finally, it considers the global situation of the Jesuits against the backdrop of an increasingly enlightened Europe and displays the ways in which Jesuit undertakings were represented and published in Manila and also in other parts of the Spanish empire. Thereby, the article develops a distinctive view on the Jesuit presence in the south of the Philippines, how they were characterized, and how they depicted themselves in the years prior to their expulsion between 1768 and 1771. It argues that, against the incremental anti-Jesuit sentiments and considerations on a global scale, the reports on their Philippine mission had the potential to counteract that aggressive atmosphere and mitigate the hostilities, by highlighting their usefulness for the Spanish colonial enterprise.

In the course of the European expansionist drive, the Spanish empire had taken possession of the Philippines in 1565 and subsequently subdued the peoples of the littoral areas of the larger islands. They established their capital in Manila, on Luzon, the largest of the islands, and started a prolific commercial system that involved above all the Chinese empire and New Spain. At the same time, the process of pacification - which had become the new term for "conquest" - was pushed ahead in the Philippines, including the subjugation of the people in the name of the Spanish sovereign, the collection of tribute, and the proselytization by the religious orders.

The Jesuits were the third order to come to the Philippines, after the Augustinians and Franciscans, and dedicated themselves above all to the proselytization of the large islands of Bohol, Samar, and Leyte, being part of the Visayan Islands, in the center of the archipelago. Since the seventeenth century, they also came to the natives of Mindanao, the second largest island, located in the south, which was ruled mostly by Muslim potentates. While the missionary work among "heathen" (people not belonging to any of the book religions) was promising and soon led to large numbers of neophytes on the Visayan Islands, the proselytization among Muslims was less successful. ${ }^{1}$

1 This article was written in the course of the Spanish projects "Dealing with the Infidel: Hispanic Diplomacy with Muslim Powers (1492-1708)" (PGC2018-099152-B-Ioo) and "Jesuitas y recoletos en Filipinas" (csic 202110Io24, no. 225595). See Horacio de la Costa, S.J., The Jesuits in the Philippines, 1581-1768 (Quezon City: Ateneo de Manila University Press, 2014 [1961]). 
The theological antagonism between the Catholic priests and the Muslim ulama (Islamic scholars), was not the only dimension of the conflict that separated Christianity and Islam in the Philippines. When the Spaniards arrived in Southeast Asia in 1565, they were quite alarmed to encounter such a large number of Muslims, their Mediterranean nemesis, in that remote part of the globe. ${ }^{2}$ Consequently, for obvious religious reasons but also for military and commercial ones, Spain challenged the Islamic influence and tried to drive the Muslims away. Thereby, they cultivated the dichotomy between both groups even more, which caused a permanent friction and led to centuries of "Moro Wars" during the whole period of Spanish colonization, between 1565 and 1898 (and beyond). ${ }^{3}$ The established form of raiding on the islands, therefore, intensified from the end of the sixteenth century and led to large warlike raiding expeditions in the following centuries. ${ }^{4}$ The Muslims, and some non-Muslim groups, attacked and destroyed Christian villages, while on the other hand, Spanish military expeditions attacked these armadas and razed Muslimdominated lands. ${ }^{5}$ Moreover, both parties enslaved their enemies, capturing

2 Isaac Donoso Jiménez, "El Islam en Filipinas (siglos X-XIX)" (PhD diss., University of Alicante, 2011); Donoso Jiménez, "Moriscos peninsulares, moros filipinos y el islam en el extremo oriental del imperio español: Estudio y edición de la Segunda carta para la S.C.M.R. acerca de los mahometanos de las Philipinas de Melchor de Ávalos (1585)," Sharq al-Andalus 20 (2011-13): 553-84; Donoso Jiménez, "Moriscos peninsulares, moros filipinos y el islam en el extremo oriental del imperio español: 2. Edición de la Primera carta para la S.C.M.R acerca de los mahometanos de las Philipinas de Melchor de Ávalos (1585)," Sharq al-Andalus 21 (2014-16): 137-63; Eberhard Crailsheim, "Wandel und Ambivalenz der Darstellung der 'Moros' auf den kolonialspanischen Philippinen (16.-17. Jahrhundert)," Saeculum: Jahrbuch für Universalgeschichte 64, no. 1 (2014): 25-40; William H. Scott, "Crusade or Commerce?: Spanish-Moro Relations in the 16th Century," in Cracks in the Parchment Curtain and Other Essays in Philippine History, ed. William H. Scott, emended ed. (Quezon City: New Day Publ., 1985); William H. Scott, "The Mediterranean Connection," in European Entry into the Pacific: Spain and the Acapulco-Manila Galleons, ed. Dennis O. Flynn, Arturo Giráldez, and James Sobredo (Aldershot: Ashgate, 2001).

3 "Moro" being the term used by the Spaniards for their Muslim enemies. Vivienne S.M. Angeles, "Moros in the Media and Beyond: Representations of Philippine Muslims," Contemporary Islam 4, no. 11 (2010): 29-53. Two classical works on the "Moro piracy" in the Philippines of the nineteenth century are Vicente Barrantes Moreno, ed., Guerras piráticas de Filipinas contra mindanaos y joloanos (Madrid: Imprenta de Manuel G. Hernández, 1878) and José Montero y Vidal, Historia de la piratería malayo-mahometana en Mindanao, Jolo y Borneo: Comprende desde el descubrimiento de dichas islas hasta junio de 1888 (Madrid: Imprenta y Fundición Manuel Tello, 1888).

4 Laura L. Junker, Raiding, Trading, and Feasting: The Political Economy of Philippine Chiefdoms (Quezon City: Ateneo de Manila University Press, 200o [1999]).

5 Cesar A. Majul, Muslims in the Philippines, 2nd ed. (Diliman, Quezon City: University of the Philippines Press, 1973); Luis C. Dery, The Kris in Philippine History: A Study of the Impact of Moro Anti-Colonial Resistance, 1571-1896 (Quezon City: Dery, 1997). 
soldiers and civilians alike. Yet, while Spaniards reduced their slaving ventures in the course of the seventeenth century, ${ }^{6}$ the Muslim practice of slave raiding even intensified, due to structural particularities and a globalizing economy, as pointed out by James Warren. The drain of men from the Philippines to the Sulu Islands and to the regional slave markets was still growing in the middle of the eighteenth century. ${ }^{7}$

Spreading the faith was the principal objective of the Society of Jesus in the early modern times. Yet, spreading the faith among Muslims was an exceptionally challenging enterprise. As the doctrines of the two religions were very close, the main arguments of the Christian missionaries could not fully develop their persuasive power. In Europe, Christian-Muslim relations ranged between brutal wars and an uneasy cohabitation. Within that European setting, the Jesuits tended to advocate a military advance against Muslims, not bothering too much with their conversion. ${ }^{8}$ In the course of their advancement in Asia, however, the perception of Muslims as resistant to conversion was nuanced. Two ways of dealing with Islam emerged, besides the military approach. First, because the Muslim population at the peripheries of their realms was considered to be only superficially Islamized, the Jesuits attempted to convert the population of these frontier regions. Second, in the center of the Muslim political power, the missionaries tried to baptize the political overlord or at least to win his favor, trying hence a top-down approach to secure a patron for the proselytization of the people.

In the Philippines, all three strategies (military push-back, bottom-up, and top-down) were attempted - all of them with limited success. First, the Jesuits constantly pushed for military campaigns of the Manila government against the

6 William H. Scott, Slavery in the Philippines (Manila: De La Salle University Press, 1991); Patricio Hidalgo Nuchera, "¿Esclavitud o liberación?: El fracaso de las actitudes esclavistas de los conquistadores de Filipinas," Revista complutense de historia de Amércia 20 (1994): 61-74; JeanNoël Sánchez Pons, "Autour d'une source: De l'esclavage aux Philippines, Xvie-Xvire siècles," Source(s): Arts, civilisation et histoire de l'Europe 7 (2015): 97-172; Déborah Oropeza Keresey, "La esclavitud asiática en el Virreinato de la Nueva España, 1565-1673," Historia méxicana 61, no. 1.241 (2011): 5-57; Tatiana Seijas, Asian Slaves in Colonial Mexico: From Chinos to Indians (New York: Cambridge University Press, 2014).

7 James F. Warren, The Sulu Zone, 1768-1898: The Dynamics of External Trade, Slavery, and Ethnicity in the Transformation of a Southeast Asian Maritime State (Quezon City: New Day Publishers, 1985, first published in 1981).

8 Daniel A. Madigan, "Global Visions in Contestation: Jesuits and Muslims in the Age of Empires," in The Jesuits and Globalization: Historical Legacies and Contemporary Challenges, ed. Thomas F. Banchoff and José Casanova (Washington, DC: Georgetown University Press, 2016), 77; Miguel Ángel de Bunes Ibarra, La imagen de los musulmanes y del Norte de África en la España de los siglos XVI y XVII: Los caracteres de una hostilidad (Madrid: CSIC, 1989). 
Philippine "moors." These were perceived as essential to defend their mission stations and to demonstrate to the Muslims the power of the Spanish troops and of the Catholic God. Second, with Muslim religious and political influence waning at the fringes of their realms, the Jesuits dared to convert Muslims and "heathen" in these frontier zones, above all in northern Mindanao. Finally, approaching the Muslim rulers in the heart of their lands, above all for diplomatic purposes, the Jesuits had the opportunity to bring Christianity closer to the ruling class and to try the top-down approach. Yet, as in other contexts, the missionaries' arguments felt mostly short to convert Muslims, frustrating in many cases their endeavors of proselytization in Mindanao and Sulu. ${ }^{9}$

In 1663, a military threat from China forced the Spanish governor-general to withdraw all forces from the south, including the garrisons in Mindanao. That meant a harsh drawback for the Jesuits' efforts, because without military support, also the missionaries had to leave their residences in Mindanao and abandon their flock. In the following years, major propagandistic attempts were started by the Society of Jesus to return to Mindanao ${ }^{10}$ and indeed Queen Regent María Teresa de Austria (r.1665-75) mandated a return in 1666 and $1672 .{ }^{11}$ Yet, despite these decrees, the Spaniards did not venture back to Mindanao for half a century.

In 1712, upon the continuous petitions of the representatives of the Society of Jesus, Philip V(r.17oo-46) issued the re-instalment of the main fort in Mindanao and in 1718, after fifty-five years of absence, a new fortress, Nuestra Señora del

9 Madigan, "Global Visions in Contestation," 83-84; Crailsheim, "Wandel und Ambivalenz der Darstellung der 'Moros"; Crailsheim, "Polarized Enemies: The Christian-Muslim Dichotomy in the Early Modern Philippines," in Philippine Confluence: Iberian, Chinese and Islamic Currents, c. 1500-180o, ed. Jos Gommans and Ariel C. Lopez (Leiden: Leiden University Press, 2020); Crailsheim, "Negotiating Peace and Faith: Jesuit Mediators between Christians and Muslims in the 17th-Century Philippines," Philippiniana sacra, no. 66.168 (2020): 375-408; Ana M. Rodríguez-Rodríguez, "Old Enemies, New Contexts: Early Modern Spanish (Re)Writing of Islam in the Philippines," in Coloniality, Religion, and the Law in the Early Iberian World, ed. Santa Arias and Raúl Marrero-Fente (Nashville, TN: Vanderbilt University Press, 2014).

10 Ana M. Rodríguez-Rodríguez, "Retorno a Zamboanga: Estrategias imperiales ante el Islam en las islas Filipinas," eHumanista: Journal of Iberian Studies 40 (2018): 374-88; Alexandre Coello de la Rosa, "Diplomáticos y mártires en la corte de Kudarat (Mindanao, siglo XVII)," Espacio, tiempo y forma: Serie IV, Historia moderna, no. 33 (2020): 323-45. Costa, Jesuits in the Philippines, 534; Majul, Muslims in the Philippines, 189-9o. 
Pilar de Zaragoza, was built on the remainders of the old one in Zamboanga. Its main purpose was to become the base for the defense of the Spanishcontrolled territory against Muslim raids and for the renewed Jesuit mission in Mindanao. Evidently, this change in the geopolitical landscape caused uproar among the Muslim polities and soon the fortress was attacked by alliances of local leaders. Yet, this time, the Spaniards had come to Zamboanga to stay and hence a new stage of war started, in which the Jesuits were again to take a very prominent position. ${ }^{12}$

This new period of Christian-Muslim confrontation was less marked by the Spanish drive to conquer but to defend its possessions, spread the Gospel, and even to intensify commerce. Yet, the Muslim neighbors felt threatened and in the subsequent years, tensions ensued even more with many polities, such as the Sulu, Maguindanao, or Maranao. At the same time, proselytization and trade were established ${ }^{13}$ and Spain entered alliances with some rulers and supported different parties within Muslim polities, taking advantages of internal frictions. ${ }^{14}$

In the first decade or so after the Spanish return to Mindanao, the Jesuits cautiously re-connected to the ethnic group of the Lutaos, some of which had held on to their Catholic faith for the time of Spanish absence. In addition, the Jesuits extended their missionary zeal and approached other native groups of Zamboanga, such as the Subanun at the west coast of the Zamboanga peninsula as well. However, recuperation was slow. Before the abandonment of the garrison, in 1663, the number of Christians in Zamboanga had been six thousand, but in 1740, it still was only half that size. ${ }^{15}$

The advocates of the return to Zamboanga had outlined the garrison's worth as best measure to curb the Muslim raids. Yet, these continued without much interference. As Zamboanga was not equipped with sufficient means to effectively block the raiders' passage, they continued to ransack Spanish villages, raising again the question in regard to the fortress' military value. The

12 Alexandre Coello de la Rosa, "Políticas geo-estratégicas y misionales en el sur de Filipinas: El caso de Mindanao y Joló (siglo XVIII)," Revista de Indias 89, no. 277 (2019): 729-63.

13 Eberhard Crailsheim, "Trading with the Enemy: Commerce between Spaniards and 'Moros' in the Early Modern Philippines," Vegueta: Anuario de la Facultad de Geografía e Historia 20 (2020): 81-111; Crailsheim, "Ambivalencias modernas: Guerra, comercio y 'piratería' en las relaciones entre Filipinas y los sultanatos colindantes a finales del siglo XVIII," in Anhelos de cambio: Reforma y modernización en las Filipinas del siglo XIX, ed. María D. Elizalde (Madrid: Polifemo, 2021), 513-42.

14 Majul, Muslims in the Philippines, 191-205; José Ángel del Barrio Muñoz, Vientos de reforma ilustrada en Filipinas: El gobernador Fernando Valdés Tamón (1729-1739) (Seville: CsIC, 2012), 57 .

15 Costa, Jesuits in the Philippines, 534-37. 
Jesuit communication strategy in these years, hence, consisted in the attempt to demonstrate to the Manila government the added value of the stronghold. Thereby, they stood in opposition to the Augustinian Recollect order-equally struggling with financial shortcomings - that supported the Spanish presence in the southwestern islands of the Calamianes and Palawan and highlighted the significance of the Fortress Santa Isabel in Taytay. Thus, there existed a strong competition between these two orders for Spanish favors and resources. To gain access to more Spanish support to reinforce their Mindanao residences, the Jesuits proposed, one the one hand, to develop Zamboanga commercially (above all through the cultivation of cinnamon), and on the other, to save money by gradually ending their unattractive missionary commitment in the Mariana Islands. The Recollects, in turn, tried to persuade the Manila government to leave the Jesuit territory in Mindanao altogether. In spite of these pleas, the Spanish monarchs in the middle of the century decided that Spain would stay in Zamboanga, as it was considered a central pillar for the stabilization of the Muslim frontier; and also the mission base in the Marianas would be maintained. Both religious orders, consequently, continued to suffer from limited support from the central government. ${ }^{16}$

Slave raiders continued to infest the Spanish Philippines in the next decades. At the same time, however, trade agreements were signed and political rapprochements took place between Manila and the sultans of Sulu and Maguindanao. Beginning in 1663 , both sultanates managed to centralize their states and reinforce their control over the other chieftains (datus). Within such a new setting, the idea of converting the ruling family gained new impetus and some priests hoped to follow in the footsteps of missionary-ambassador Alexandro López (1604-55). ${ }^{17}$ Yet, the proselytization of the many "heathen" and Muslims at the fringes of the sultanates was still the main objective of the Jesuit missionaries in Mindanao. ${ }^{18}$

At the beginning of the eighteenth century, the Sultanate of Maguindanao had entered an unstable phase, leaving much political leeway to smaller local leaders. The Sulu Sultanate, on the other hand, had continued its centralization

16 Coello de la Rosa, "Políticas geo-estratégicas y misionales"; Eduardo Descalzo Yuste, "La Compañía de Jesús en Filipinas (1581-1768): Realidad y representación" (PhD diss., Universidad Autónoma de Barcelona, 2015), 243-44.

17 Crailsheim, "Negotiating Peace and Faith"; Crailsheim, "The Baptism of Sultan Azim ud-Din of Sulu: Festivities for the Consolidation of Spanish Power in the Philippines in the Middle of the Eighteenth Century," in Image-Object-Performance: Mediality and Communication in Cultural Contact Zones of Colonial Latin America and the Philippines, ed. Astrid Windus and Eberhard Crailsheim (Munster: Waxmann Verlag, 2013).

18 Barrio Muñoz, Vientos de reforma ilustrada, 68-69; Costa, Jesuits in the Philippines, 537. 
efforts and, by 1730, it stood at the height of its power. Both sultans refrained from raiding activities themselves but collaborated silently with the local datus, who even intensified their attacks on the Visayas. Governor-General Fernando Valdés Tamón (in office 1729-39) took tough actions against these raiders and sent ships to retaliate. More sustainable, however, were his instructions to the fortress garrisons to engage in corso, i.e. the legitimization to attack any Muslim ship in sight. Valdés Tamón's grand design consisted, moreover, of a defensive strategy that included first, a permanent armada in the Visayan Islands of fifteen to twenty caracoas (large, fast Filipino boats), which would act in collaboration with the armadas of Cavite (in Luzon), Zamboanga (Mindanao), and Taytay (Palawan), second, the unification of native villages to larger units for a better defense (an old project, in fact, but with new impulse), and third, a more active participation of natives in the coastal defense, mainly in the form of corso, under the auspices of the village priests. ${ }^{19}$

\subsection{The Jesuits Facing the Sultans Azim ud-Din and Amir ud-Din}

One of the greatest threats to the Spaniards in these years was Sultan Badar ud-Din (r.1718-32), who expanded commercially toward China and militarily by attacking the Spaniards in Palawan. The Spaniards retaliated by attacking Sulu and burning plantations and orchards. In return, the Sulu attacked the two most important Spanish forward posts, Zamboanga (December of 1634) and Taytay (1635). In 1735, Datu Lagasan, the son of Badar ud-Din, assumed the throne and became the new sultan, taking the name Azim ud-Din (r.1735-48 and $1764-74) .{ }^{20} \mathrm{He}$ was the candidate of the pro-Spanish fraction and hopes for peace, alliance, commerce, and proselytization were high among the Spaniards, in particular amongst the Jesuits. Azim ud-Din was a widely travelled man and well versed in theology. He had studied in Batavia, gone to China, visited the governor of Zamboanga several times, and repeatedly expressed his desire to visit Manila. In 1737, both parties concluded a treaty of friendship and commerce on equal basis, including a paragraph on together punishing raiders on Spanish territories. When internal tensions emerged in the Sulu reign between 1740 and 1742, Spain supported Azim ud-Din and enabled him to stay in power. The sultan thus seemed to remain dependent on Spanish aid during all of these years and Manila used this leverage in 1747 to obtain his support to defeat raiders from Borneo (nominally under Sulu rule) that were a constant nuisance to the Philippine coastline. ${ }^{21}$

19 Barrio Muñoz, Vientos de reforma ilustrada, 70, 73, 85-88, 96-97.

20 Majul, Muslims in the Philippines, 20, 195.

21 Majul, Muslims in the Philippines, 198-200; Costa, Jesuits in the Philippines, 537. 
In 1744, on request of the Jesuit José Calvo (1681-1757), ${ }^{22}$ Philip V wrote letters to the sultans of Sulu and Tamontaca, ${ }^{23}$ which reached their addressee in $1747 .{ }^{24}$ Azim ud-Din received his letter through the hands of Ambassador Tomas Arrivillega and the Jesuit Sebastian Ignacio Arcada. It contained the king's guarantee for the sultan's sovereignty and the request to allow the Jesuit missionaries to establish churches and preach the Gospel in his realm, which had been left out in the treaty of 1737 . The ambassadors were warmly welcomed and well treated. The king's wishes were granted by the sultan and the Jesuits were allowed to build a church in Sulu and proselytize; the sultan also uttered that he might consider Christianity himself someday. In return for these favors, Azim ud-Din received money and weapons from Manila.

By then, the Spaniards had understood that the sultans were after all just primi inter pares and, hence, unable to go against the majority of their datus. Thus, by backing pro-Spanish candidates and their fractions, like Azim ud-Din and his supporters, the Manila government could influence the internal politics of the sultanates in their favor. As another example of this strategy, in Tamontaca, Sultan Amir ud-Din Hamza (also called Muhammad Khair ud-Din, r.1734-55) received much Spanish support in the civil war in Mindanao against his rival Malinog. In 1734, Spain and Amir ud-Din signed a treaty of peace and collaboration, which improved mutual relations. ${ }^{25}$ King Philip v's letter was delivered as well in 1747 by Tomas Arrivillega and another Jesuit, Francisco Sassi (Zassi). While Amir ud-Din also replied positively to the request, his commitments were much less concrete than those of the Sulu sultan due to internal opposition. The Jesuits could not enter his lands freely at first. Only in September of 1748, Ignácio Malaga and Juan Moreno managed to access the sultanate but soon they had to learn that neither the sultan nor the people were willing to accept their preaching. Therefore, the project of the proselytization in Maguindanao was already stopped after six months and the Jesuits' efforts remained more directed at the Sulu Sultanate. ${ }^{26}$

In Sulu in the 1740s, Azim ud-Din still depended much on Spanish support to keep the opposing party in check. Frequently, he went to Zamboanga and talked to the German Jesuit Jose Villielmi (Josef Wilhelm), who believed Azim ud-Din's susceptibility for Christianity. Some months after the reception of

\footnotetext{
22 See https://dbe.rah.es/biografias/19936/jose-calvo (accessed November 17, 2021).

23 Tamontaca was one of the two rival capitals of the Maguindanao sultanate at that time.

24 Montero y Vidal, Historia de la piratería, 2: appendix, 6-9.

25 Barrio Muñoz, Vientos de reforma ilustrada, 96-117.

26 Majul, Muslims in the Philippines, 205, 216-17; Costa, Jesuits in the Philippines, 538, 540.
} 
Philip v's letter in Sulu, Pedro de Estrada, the Jesuit superior provincial (in office 1744-48), sent four more Jesuits to Zamboanga, with their staff of servants and artisans, to increase the endeavor to spread the faith in the south of the Philippines. Their task was to preach the Gospel, reassure the sultan in Sulu of their good intentions, free captive Christians, and, above all, to apply the top-down approach and convert the sultan and his family. The sons of the Sulu elite, in turn, would be sent to Manila to study. Unfortunately, half of the Jesuit missionaries died of an epidemic and when, on May 5, 1748, Azim ud-Din arrived in Zamboanga to take the missionaries with him, only Juan Anglés and Patricio del Barrio were able to accompany him. Soon, the two Jesuits found out that Azim ud-Din only controlled one third of the capital and that the opposition against him (and the missionaries) was overwhelming. Consequently, they had to stay within the compound of the palace and were barely able to preach to the people. Also, despite the descriptions of older accounts, detailing that Islam was not deeply rooted, Juan Anglés learned that in Sulu their conviction was strong and that the words of the Gospel found almost no repercussion. Obviously, Azim ud-Din was in a difficult situation. While the ulama and the datus considered him a knowledgeable ruler, they perceived his tolerance for the missionaries as weakness and even as heresy. The missionaries, on the other hand, were disappointed as they could barely pursue their work and encountered obstacles on every corner. They were also displeased because they had almost no access to the royal family and Muhammad Israel, the sultan's son, who had been tutored by Jesuits before, was now being instructed by Muslim teachers. Trying to please both fractions, the sultan ended up disappointing both and on September 1, 1748, he was ousted by Bantilan, his brother. Azim ud-Din fled with seventeen ships from Sulu to Zamboanga and later to Manila to ask again for Spanish support. The two Jesuits who had remained in Sulu were not expelled but they did not feel secure any more and returned to Zamboanga soon after. ${ }^{27}$

The events in Sulu convinced the Jesuits, and in particular Anglés, that Azim ud-Din was not to be trusted, but the other religious orders did not share this perception. As soon as the sultan had arrived in Manila, the other fraction pushed for the conversion of the sultan to Catholicism and, led by the Dominican interim governor-general Juan de Arechederra (in office $1745^{-5}$ ) ),

27 Juan de Arechederra, O.P., Relación de la entrada del Sultan Rey de Jolo Mahamad Alimuddin en esta Ciudad de Manila (Manila: Colegio de Santo Tomas, 1750); Majul, Muslims in the Philippines, 206-18; Costa, Jesuits in the Philippines, 537-43; Barrio Muñoz, Vientos de reforma ilustrada, ${ }^{128-35}$. 
they even managed to baptize him in $175^{\circ} .{ }^{28}$ The Jesuits opposed that baptism from the beginning, not believing the sultan's intention anymore. In general, they started to take a harder stance against the Muslims in the Philippines. This is most visible in the words of Anglés, who in a letter from 1748 resumed his experiences and knowledge of the past century of Spanish-Muslim relations in the Philippines. Very disillusioned, Anglés wrote that the Sulu had never kept peace with Spain or amongst themselves and also in the future they would never be trustworthy. They were "pirates," "cowards," "traitors," and never kept their word. Having seen their defenses, Anglés was of the opinion that, following the example of former war heroes like Governor-General Concuera de Hurtado (in office 1635-44), Spain could conquer the sultanate without much ado, taking advantage of their lack of natural supplies on Sulu. ${ }^{29}$ Hence, in these years, a shift in the Jesuit perspective can be perceived, from the topdown approach to an approach with a stronger military component.

\section{The Jesuits in the Military Conflicts of the 1750s}

In 1751, the new Spanish governor-general, Francisco José de Ovando (in office 1750-54), sent an expedition to Sulu to reinstall the baptized Sulu sultan Azim ud-Din, who had been given the name Fernando I, king of Sulu. The expedition went awry and triggered an intensification of the Muslim-Christian conflict in the region. The Spanish field marshal Ramón Abad laid waste to Sulu, while Maranao raiders attacked Spanish settlements in the thousands, starting one of the bloodiest phases of the conflict. ${ }^{30}$ By then, the strategic importance of the presidio of Zamboanga had been sufficiently demonstrated and between $175^{\circ}$ and 1753, a project was taken up again to resettle people from Bohol in its vicinity, to provide the Spanish garrison with farmers and auxiliary troopsmuch to the delight of the Jesuits. In the end, however, the project came to nothing. ${ }^{31}$

In Madrid, these years were marked by the pro-French and anti-British government of the Marques de Ensenada (in office 1702-81), who simultaneously presided over several important ministries between 1743 and 1754. Ensenada

\footnotetext{
28 Eberhard Crailsheim, "The Baptism of Sultan Azim ud-Din of Sulu."

29 "Demostración histórica de cuantas depredaciones llevan cometidas los moros," in Guerras piráticas de Filipinas contra mindanaos y joloanos, ed. Vicente Barrantes Moreno, 210-14.

30 Costa, Jesuits in the Philippines, 542-43.

$31 \quad$ Javier Ortiz de la Tabla Ducasse, El marqués de Ovando: Gobernador de Filipinas (1750-1754) (Seville: CSIC, 1974), 197-201, 217.
} 
put much effort into strengthening the coastal defenses of the Spanish colonies and fortifying its maritime power in the key areas. ${ }^{32}$ During that time, Governor-General Ovando in Manila considered shifting from a defensive to an offensive approach to the southern Philippines. On February 6, 1753, he turned to four experts for military advice, two military officers and two Jesuits, namely, the superior provincial Juan Moreno (in office 1750-54 and 176o-61) and Juan Anglés. ${ }^{33}$ Interestingly, the advice of the Recollects was not requested at that time. Once Ovando felt sufficiently informed, he sent a report and a request to Madrid and waited for the necessary reinforcements for an attack on Sulu, Borneo, and Mindanao. In the meantime, the fortifications were strengthened, because Sulu, Tirun, and Maranao raiders laid havoc on Spanish villages in Mindanao and the Visayas.

In spite of the raiders' attacks, the missionaries of the different orders continued with their task of administering the native parishes. In addition, they supported and led the natives in the construction of protective structures (fortresses, churches, convents, or watchtowers) and to organize the village defense. Moreover, the natives were encouraged to become more active in corso-activities by conceding them the bulk of the spoil from enemy vessels. ${ }^{34}$ In spite of these measures, the raids and depredations intensified. The offensive envisioned by Ovando never materialized and, hence, the Philippines remained stuck for the next decades in a permanent defensive war at their coastlines, with only few exceptions.

\subsection{The Siege of Palompong and the Successful Resistance of Native Villages}

In 1754 and 1755 - a noticeable height of raiding activities - two Jesuit booklets were printed that depict the destruction and cruelties of the raids, the suffering of the natives, and the important role of the Jesuit missionaries. Both shall be discussed on the following pages, as they have the potential to first illustrate the role of the Jesuits in the southern Philippines as missionaries and military commanders, and second, enable an analysis of the communicative strategy of the Jesuit order in regard to the Philippines. The first one is called Relación de la valerosa defensa de los Naturales de Bisayas del Pueblo de Palompong en la Ysla de Leyte, de la Provincia de Catbalogan en las Yslas Philipinas, que hicieron contra las Armas Mahometanas de Ylanos, y Malanaos, en el Mes de Iunio

\footnotetext{
32 Coello de la Rosa, "Políticas geo-estratégicas y misionales," 757.

33 Ortiz de la Tabla Ducasse, Marqués de Ovando, 209.

34 Montero y Vidal, Historia de la piratería, 2: appendix, 29-30 (bando del gobernador de Filipinas, octubre de 1751); Ortiz de la Tabla Ducasse, Marqués de Ovando, 208, 217.
} 
de 1754 (Relation of the valorous defence of the Bisayan natives of the village of Palompong, in the Island of Leyte, of the province of Catbalogan, in the Philippine Islands that they made against the Mahometan forces of Ylanos and Malanaos, in the month of June, 1754) and was published in the Jesuit printing press in Manila at the end of $1754 \cdot{ }^{35}$

The main event of the booklet is the attack on the Spanish-ruled village of Palompong, on the Island of Leyte in June 1754. In the absence of the village priest, 335 villagers gathered in the church compound to withstand the attack of a thousand Iranun and Maranao raiders, who in that time were replacing the Sulu as most fearful foes. After nine days, the attackers left again without being able to breach the walls. The report highlights the valor of the villagers, the divine provision by Saint Francis Xavier (1506-52), and the waist the raiders laid on the village. After narrating these events, the report provides additional information of other raids, mainly on Jesuit villages in Luzon, the Visayas, and Mindanao, all of which were repulsed by the natives.

In the 175os, the disastrous state of the Spanish military and its weakness against the raiders became most evident. Sulu, Maranao, Iranun, Maguindanao, and other neighboring ethnicities attacked Spanish villages at will and dominated the Philippine waters. The offensive plans of the government had collapsed and also the defensive schemes seemed to fail. The coastguard system was far from working, as too little ships existed and those in use were too slow. The idea to activate the natives in an open sea offensive against the enemy (corso) was working only in very few places, and the ramparts in the villages were often too weak for a successful defense. Consequently, the natives found little trust in the Spanish protective power and grew weary of their colonizers, for whom they even had to pay a special tribute for their protection. ${ }^{36}$ For most of them, leaving the villages (mostly founded some decades ago by priests) and returning to smaller settlements and more hidden spaces would have been the most obvious choice. However, that was not in the sense of the missionaries, who would have lost most of their flock, or of the Spaniards, who would have

35 Relación de la valerosa defensa de los Naturales de Bisayas del Pueblo de Palompong en la Ysla de Leyte (Manila: Impr. de la Compañía de Jesús, 1754); an English translation: "Moro Raids Repulsed by Visayans: Defense of Palompong 1754," in The Philippine Islands 1493-1803, vol. 48, ed. Emma H. Blair and James A. Robertson, 55 vols. (New York: Kraus Repr., 1962 [19039]), 37-51; Crailsheim, "Polarized Enemies."

36 Eberhard Crailsheim, “¿Fortalecer la cohesión interna?: El 'peligro moro’ en las Filipinas coloniales en la segunda mitad del siglo XVIII," in Filipinas, siglo XIX: Coexistencia e interacción entre comunidades en el imperio español, ed. Xavier Huetz de Lemps and María D. Elizalde (Madrid: Polifemo, 2017); Francisco Mallari, S.J., "The Spanish Navy in the Philippines, 1589-1787," Philippine Studies 37, no. 4 (1989): 412-39. 
lost much of their tribute. Hence, the missionaries put a lot of effort into convincing the villagers to stay. The Relación de la valerosa defensa can be read as one prominent module of the Jesuit attempts to discursively persuade the villagers to stand their ground against the raiders and to not abandon their villages. At the same time, the missionaries supported the natives in an effective protection of their settlements. Usually, they administered the construction of defensive building structures, ${ }^{37}$ organized support from Manila, and gave a rudimentary military training to the villagers. ${ }^{38}$ Yet, sometimes, they even went further, as the example of the Jesuit José Ducós will show.

\subsection{The Jesuit José Ducós and the Misamis-Campaign of 1754}

José Ducós was born in Barcelona in 1724, son of a colonel of the Spanish army. In 1739, he entered the Jesuit novitiate in Tarragona. He went to New Spain and in 1749 he was ordained a priest and sent to reinforce the Jesuit province in the Philippines. Between $175^{2}$ and 1759, Ducós became one of the champions in the Spanish wars against the Muslim raiders of the Maranao, who is still well remembered as prominent figure in recent texts on local history. ${ }^{39}$

In a Philippines Studies article from 1968, "Father Ducós and the Muslim Wars, 1753-1759," Miguel Bernad, S.J., states that "the story of Father Ducós and of the Moro Wars of the 1750's may be pieced together from the works of four historians," namely Juan de la Concepción, O.A.R., Joaquin Martínez de Zuñiga, O.S.A., José Montero y Vidal, and Vicente Barrantes. ${ }^{40}$ Evidently, much can be learned from these eighteenth- and nineteenth-century authors about the events surrounding that resolute missionary in northern Mindanao. However, after half a decade, it is time to re-consider these events and take another look at the illustrious "padre comandante," based on the oldest printed account, the booklet Compendio de los Sucesos que con gran gloria de Dios, Lustre y Honor

37 René B. Javellana, S.J., Fortress of Empire: Spanish Colonial Fortifications of the Philippines, 1565-1898 (Manila, Makati City: Bookmark, 1997).

38 James F. Warren, Iranun and Balangingi: Globalization, Maritime Raiding, and the Birth of Ethnicity (Quezon City: New Day Publishers, 2002), 110.

39 Lhem J. Naval, The Grand Northwest of Mindanao: Vignettes of Misamis History and Other Essays (Magsaysay, Balingao, Misamis Occidental: Synoptika, 2014); Naval, "Triunfo: Padre Jose Ducos, SJ and the Misamis Fortress," Center for Misamisnon Culture and History, April 19, 2020, https://misamishistory.wordpress.com/2020/04/19/padre-jose-ducos-sj-and-themisamis-cotta/ (accessed November 21, 2021).

40 Miguel A. Bernad, S.J., "Father Ducos and the Muslim Wars, 1753-1759," Philippine Studies 16, no. 4 (1968): 69o-728, here 727; Miguel A. Bernad, S.J., The Great Island: Studies in the Exploration and Evangelization of Mindanao (Quezon City: Ateneo de Manila University Press, 2004), 98-99. Out of the four, Juan de la Concepción, O.A.R., Historia general de Filipinas: Conquistas espirituales y temporales de estos españoles dominios establecimientos 
de las Catolicas Reales Armas de S.M. en defenda de estas Christiandades, e Islas Bisayas, se consiguieron contra los Mahometanos Enemigos por el armamento destacado al presidio de Yligan sobre las Costas de Isla de Mindanao 1754 (Compendium of events that, with great glory of God, brilliance and honor of the Catholic royal arms of H.M. in defense of these Christianities, and Visayas Islands, were obtained against the Mohammedan enemy by the armament detached at the Iligan garrison at the coasts of the Island of Mindanao, 1754), published in the Jesuit printing press in Manila in the following year. ${ }^{41}$

Shortly after his arrival in Manila, José Ducós was sent to the Jesuit residence in Iligan. ${ }^{42} \mathrm{He}$ did not have much time to adapt and was thrown right away into the conflict between Spanish villages and Muslim forces. In 1753, the city of Iligan was attacked and besieged by two thousand Maranao warriors. Within the walls of a stone fort, thirty Spanish soldiers and ten from Pampanga supported the local villagers. Amongst them was also Father Ducós, who had a leading role in the organization of the defense. After about two months, the siege was lifted and Iligan was freed. ${ }^{43}$ Together with the Spanish administrator (corregidor) of Iligan, Felipe Carvallo, Ducós wrote a letter to Manila, depicting the dangerous situation Iligan was in and highlighting the strategic importance of the place in the fight against the Maranao raiders. From the Iligan area, all Maranao ships (joangas) could be prevented from leaving Pangil Bay for their annual raiding tours in the Philippines. Governor-General Ovando took the threat to Iligan and its garrison seriously and mandated the establishment of another fortress even closer to the enemies, at the mouth Pangil Bay, in Misamis. To strengthen the Spanish presence in the south, as part the offensive scheme mentioned above, Ovando sent two fleet there. The larger one went to

progresos y decadencias (Madrid: Impr. del Seminar. Conciliar y Real de S. Carlos, Agustín de la Rosa y Balagtas, 1788-92), provides most relevant information. Large parts of volume 13 (chiefly chapters $6-7,10,14$ ) and some passages of volume 14 (mainly chapter 10; it also contains much information on the confrontation between Jesuits and Recollects) relate the events of Iligan and the actions of José Ducós from a Recollect view. See Montero y Vidal, Historia de la piratería, vol. 1, chapters 17-20, esp. 301-2; 313-15, 319, 325, 333; Joaquín Martínez de Zúñiga, O.S.A., Historia de las Islas Filipinas (Sampaloc: Fray Pedro Argüelles de la Concepción, 1803), 377-78 (chapter 32); "Demostración histórica de cuantas depredaciones llevan cometidas los moros," esp. 61-63 (published by V. Barrantes).

Compendio de los Sucesos (Manila: Imprenta de la Compañía de Jesús, Don Nicolas de la Cruz Bagay, 1755); to be found in the Archivo General de Indias [hereafter AG I], Filipinas 386, N. 14 .

42 A contemporary map depicting the relevant a zone can be found online on the Library of Congress webpage: https://www.loc.gov/resource/gdcwdl.wdl_10o89 /?r=0.531,0.713,0.144,0.094, (accessed November 29, 2021).

Bernad, "Father Ducos and the Muslim Wars," 704-7. 
Zamboanga, while the smaller one sailed to Iligan, to support Father Ducós's initiative. The commander of the fleet was Miguel Gómez Valdés. ${ }^{44}$

The Iligan fleet consisted of three galleys and some smaller vessels with a considerable force of two hundred Spanish troops and five hundred local ones, above all from Bohol. On April 25, 1754, Captain Pedro Alcántara Pérez arrived with the major part of the contingent, much to the delight of the people of Iligan. The preparations for an offensive started immediately and when Gómez Valdés arrived on June 2, the campaign was prepared to start right away. In regard to local expertise, Ovando's orders were clear: the advice of Ducós had to be taken into account in all important matters. But Ducós's involvement consisted in more than administering advice. He was part of the expedition and while the larger galleys were commanded by Spanish officers, he was in charge of a fleet of smaller vessels (bancas, vintas, and sacayans) to block the Maranao from entering the Mindanao Sea from the rivers. Right from the start, the project was a success. Fifty-five enemy vessels were captured and the control of the mouths of Pangil Bay and important rivers was secured. In addition, the men of Iligan successfully attacked an enemy village by land under their native commander Pedro Tamparong.

After these first campaigns, on June 15, Gómez Valdés left with one of the galleys for Zamboanga - not without complaining that his officers were rather following Ducós's orders than his own. ${ }^{45}$ Gómez Valdés was not depicted in the best of colors in the Jesuit sources-he arrived too late in Iligan and left too early for Zamboanga. Some of his leading officers, however, were conducting very successful military campaigns, showing outstanding leadership. The remaining troops were placed under the command of Captain Lázaro de Elizavera, commander of the galley San Phelipe. The other galley, the Triunfo, was placed under Captain Nicolás Afriano. In the meantime, Governor-General Ovando was relieved in Manila by Pedro Manuel de Arandía Santisteban (in office 1754-59), who happened to have known Colonel Ducós, the Jesuit's father. Convinced of José Ducos's military capacities, he transformed his informal "special commission" into an actual military command and made him captain-general of the fleet on July $16 .^{46}$

The campaign intensified with the goal to further block the passage of the Maranao between the rivers and the Mindanao Sea, by more thoroughly cutting off two rivers, the Linamon and the Liangan, and the mouth of Pangil Bay.

44 Bernad, "Father Ducos and the Muslim Wars," 708-10; Montero y Vidal, Historia de la piratería, 1:302.

45 Concepción, Historia general de Filipinas, 13:187-88.

46 Bernad, "Father Ducos and the Muslim Wars," 710-13. 
The undertaking was a big success. In particular, Captain Afriano managed to destroy several enemy ships in many sea battles at the bay, defeat countless raiders, and free numerous Christian captives. José Ducós was mainly in charge of the Bohol and Iligan fleets and successfully fought the enemy at the Liangan River. Between July and October of 1754 , the Spanish side did not lose a single battle. ${ }^{47}$ In all of these confrontations, the troops from Bohol stood out as valiant units and also the men from Iligan bravely defended their villages. Moreover, also the Bukidnon, an independent, non-Christian group, joined ranks with the Spaniards and fought the Maranao. ${ }^{48}$

Father Ducós participated and led many of these skirmishes between June and August of 1754. Yet, on August 23, 1754, in a long and bloody encounter with sixteen enemy vessels, he was seriously hurt by an exploding cannon (pedrero), which knocked him unconscious, rendered his right hand useless and blinded him permanently in the left eye. The battle was won, thanks to Pedro Tamparon and his men from Iligan but Ducós had to be brought to neighboring Cebu for treatment. The successful expeditions, however, continued without Ducós and even provided much spoil, in the form of cannons, weapons, or sacred church vessels that could be retrieved. By October 1754, Ducós had recovered from most injuries and returned to Iligan, resuming his command. All in all, almost 160 enemy vessels were taken and five hundred Christian slaves were freed between July and December of 1754 . In regard to human losses, the Spanish sources report that two thousand enemies were slain, while—allegedly—not a single man was lost on the Spanish side. ${ }^{49}$

When the news of the victories reached Manila, a Te Deum was sung in the cathedral in the presence of the Spanish elite on January 28, 1755 and the whole city rejoiced upon the good news from the southern front-being a welcome change after many years of bad news. The Spanish authorities, upon learning from the success, endorsed the construction of a stone fort in Misamis, to permanently block all Maranao traffic. In addition, a Spanish fleet of two galleys and twelve vintas was ratified, which was placed under the command of natives, namely Pedro Tamparong from Iligan and Ignacio Cabiling from

47 In the words of the booklet: "Por estos dias fueron tan repetidas las funciones, y tan una sobre otra, que no a sido possible hacer distinction de cada una; con el zelo de acudir, y ayudarse los unos a los otros de los nuestros, se dejó de numerar los muchos Cautivos Christianos, que se redimieron, como el computo de la mortandad Enemiga; y baste decir, que en todas las ocasiones pequeñas, y grandes salieron venturosos nuestros Combatientes." Compendio de los Sucesos, 17.

48 Bernad, "Father Ducos and the Muslim Wars," 713-20, 723.

49 Bernad, "Father Ducos and the Muslim Wars," 720-23. 
Dapitán. Moreover, Ducós was confirmed in his position as captain-general of all naval campaigns, which was approved in Madrid—although with some astonishment in regard to a military rank for a Jesuit missionary. By 1756 , the stone fort, named Triunfo (Triumph), was finished and until 1759, the campaigns of Pangil Bay continued to be quite successful. By then however, financial constraints forced the new interim governor-general of the Philippines and bishop of Cebu, Miguel Lino de Ezpeleta (in office 1759-61), to divide the Misamis forces. This measure was intended to create a more secure environment for eastern Mindanao, in particular for the parts administered by the Augustinian Recollects, which at that time were more prone to raiders. Its effect, however, was that the Maranao could now bypass the fewer Spanish vessels in Misamis and join the Sulu, Maguindanao, and Iranun in their raids on the Visayan Islands. The internecine competition between the two religious orders in this case seemed to have produced a very negative effect on Christian settlements in the Philippines after 1759, as they again suffered extreme hardships through the Maranao raiders. ${ }^{50}$

In the middle of the eighteenth century, in spite of the intensity of the war against the raiders, the Jesuits were thriving in the Philippines. Historian Descalzo Yuste even states that these years represented the height of stability of their presence on the archipelago. ${ }^{51}$ The Society owned various houses and latifundia, a pharmacy, and a printing press. It had a good income, supervised numerous parishes and missions, and above all, its contribution to the educational system of the colony was highly esteemed. ${ }^{52}$ Back in Europe, however, the Jesuits had moved more and more to the center of critique of the enlightened intellectuals and rulers and were much in the defense. In reality, the Society had been exposed to severe critique since the very beginning,

50 "Relación breve de lo sucedido en Philipinas, escrita en 1754," in Cartas edificantes, y curiosas: Escritas de las missiones estrangeras, y de Levante por algunos missioneros de Compañia de Jesús, ed. Diego Davin, S.J., 16 vols. (Madrid: Imprenta de la viuda de Manuel Fernández, 1754-57), 16:21; Bernad, "Father Ducos and the Muslim Wars," 723-25. For the confrontation between both orders at the height of the war against the raiders in the words of José Ducós, see AGI, Filipinas 16o, N. 10, s.n., "Testimonio 1: Copia de la carta de 23 de junio de 1754 de José Ducos, de la Compañía de Jesús a Pedro Manuel de Arandia sobre dificultades con los agustinos."

$5^{1}$ Descalzo Yuste, "Compañía de Jesús en Filipinas," 231, 25 o.

$5^{2}$ Costa, Jesuits in the Philippines, 545-88. 
but in the middle of the eighteenth century, this situation reached its peak. In the overseas missions, the resistance of the Jesuit order against the Treaty of Madrid of $175^{\circ}$ (new lines of separation between Spain and Portugal) and the admonishments of the ills of the reducciones in Paraguay reinforced the already existing mistrust against the order. They had to shield themselves against accusations of structural despotism, uncertain loyalties, concealment, arrogance, moral corruption, backwardness, and the pursuit of economic gains and political power. ${ }^{53}$

It would be wrong to simply ignore these critical anti-Jesuit currents just because they were not so strongly felt in the Philippines. While it seems that the discussion about the allegedly corrupt character of the order was not very intense in the archipelago, the members of the order still felt the need to highlight their usefulness even more than usual. The competition with other religious orders, aware of the waning strength of the Jesuits, was a strong factor in that regard. Evidently, the renowned Jesuit chroniclers of the seventeenth century, Pedro Chirino, Francisco Colín, Francisco Combés, or Francisco Ignacio Alcina, and of the early eighteenth century, Diego de Oña and Pedro Murillo Velarde, put much effort into stressing the worth of the Society in the Philippines. Yet, these chronicles were not the type of medium that was able to get the attention of an increasingly sophisticated audience, eager to get the gist of the latest happenings as fast as possible. Small booklets, such as those discussed above, on the other hand, could transmit information much faster-and the Jesuits had their own printing press in Manila.

Taking another look at the two booklets depicting the defense of Palomong and the deeds of Father Ducós, the intentions of the authors and the publishers become visible. Very prominent was the appeal to get more support from the Manila government. This support could take the form of military help through coast guard fleets or supplies of weapons, gunpowder, canons, troops, or ships; it could also mean tax exemptions or other benefits for the fighting natives. ${ }^{54}$ The Ducós booklet also stressed the worth of good commanders, while at the same time, it denounced the misconduct of others. In addition, both booklets encourage active resistance of the native people under Spanish rule, highlighting the success of native defensive and offensive initiatives even against large numbers of enemies. As indicated above, this message was essential in the Jesuit communication with the natives, to convince them to defend their villages instead of abandoning them.

53 Markus Friedrich, Die Jesuiten: Aufstieg, Niedergang, Neubeginn (Munich: Piper, 2018), 526-37.

54 Crailsheim, “¿Fortalecer la cohesión interna?” 
Finally, the texts strove to show the great worth of the Jesuit missionaries in extremely difficult situations in frontier zones. Evidently, the spread of the Gospel was the main purpose of the missionaries, as pointed out by Chirino and Colin, and also the cultural and social advancements achieved by the order were important, as emphasized by Murillo Velarde. In the two booklets, furthermore-in accordance with the seventeenth-century Historia of Francisco Combés - the military value of the Jesuits was highlighted. The texts depict them as essential personnel of the Spanish crown in its remotest colony, be it in defensive or in offensive operations. The message was conveyed that it was above all the strong will and determination of the stout Jesuit missionaries that upheld the Spanish banner against the onslaught of the forces of the archenemy, serving as advance post and first line of defense for the whole of the colony and the empire. In this regard, only the Augustinian Recollect order could state to be of similar value to the Manila government, due to its activities in the east of Mindanao and in the Calamianes and Palawan areas.

In Europe, the adventures of daring Father Ducós and his Boholano warriors even made it into a prominent edition of the Jesuit annual letters, the Cartas edificantes $y$ curiosas (1754-57) of Diego Davin, ${ }^{55}$ which shows that these events and the Jesuits' achievements in the Philippines were deemed interesting enough and useful to be presented to a larger audience. Even if Ducós's actions probably did not make the Jesuits more likeable for enlightened thinkers or for Jansenists, they emphasized their general potential and usefulness for the colonial states and for the Spanish empire in particular. In the Philippines, at least, the booklets served its purpose to put public pressure on the government to support Jesuit requests. As Bernad puts it, "nothing succeeds like success," ${ }^{\prime 5}$ and indeed shortly after the news of Ducós's achievements were known, more ships were sent and resources were made available to support his missionary-led fleet in Misamis.

Shortly after, the events in Europe came thick and fast and the Society of Jesus was ousted in Portugal (1759) and France (1761). Yet, in Spain, things seemed well for the time being. Carlos III (r.1759-88) had other things on his mind, as he had to struggle with the British in the Seven-Years' War (1756-63). In October 1762, British troops even took Manila by surprise. In the following year

55 "Relación breve de lo sucedido en Philipinas, escrita en 1754," 1-31.

56 Bernad, "Father Ducós and the Muslim Wars," 723. 
and a half, the capital of the Spanish Philippines was in their hands and only some high Spanish officials, supported by native troops, resisted them in the rural areas. During these years, when the sheer existence of the colony was at stake, the skirmishes at the southern frontier and the raids in the Visayas were not in the center of attention of the Spanish exile government. Cut off from their superiors and from the Spanish government, the Jesuits in Mindanao were basically left on their own, unable to further develop their missions or to extend their offensive. The same was true for the following years, when the preparation against another potential British invasion was the biggest concern in Manila. ${ }^{57}$

In 1767 , Carlos III disbanded the Jesuit order in the Spanish empire in a coup de main. At that time, 143 members of the order worked in the Philippines, six of them in the residencia of Dapitan and two more in the colegio of Zamboanga. None of them resisted the royal decree and between 1769 and 1771 all, who were in conditions to travel, were sent to Spain. The Mindanao mission was entrusted to five members of the order of the Augustinian Recollects, one of whom went to Zamboanga. Only in 186o, would the Society of Jesus be able to return to the Philippines, and take Mindanao back again. ${ }^{58}$

At the convergence of Asian and Spanish zones of influence, the Jesuits played an essential role as proselytizers for the natives, as intermediaries between Spaniards and Muslims, and as ambassadors and even military commanders of the Spanish empire. While on the one hand, they were legates of the Roman Catholic Church, they were also part of the Spanish colonial project, aimed at producing and protecting good native citizens and taxpayers and expanding the empire's borders. In the Philippines, these tasks were closely linked to the issue of the Muslim sultanates and their constant raids on the Spanish colony.

57 Nicholas Tracy, Manila Ransomed: The British Assault on Manila in the Seven Years' War (Exeter: University of Exeter Press, 1995); Shirley Fish, When Britain Ruled the Philippines, 1762-1764: The Story of the 18th-Century British Invasion of the Philippines during the Seven Years' War (Bloomington, Ind.: 1stBooks Library, 2003).

$5^{8}$ María Aguilera Fernández, "La reimplantación de la Compañía de Jesús en Filipinas: De la Restauración a la Revolución Filipina (1815-1898)” (PhD diss., Universidad Autónoma de Barcelona, 2018), 58-66; Santiago Lorenzo García, La expulsión de los jesuitas de Filipinas (Alicante: Universidad de Alicante, 1999), 73-74; Pablo S. Pastells, S.J., Mission to Mindanao, 1859-190o (Cebu City: University of San Carlos Press, 1994). 
In their approach to the Islamic south, the Jesuits pursued three different methods of missionary expansion: military push-back and bottom-up and topdown proselytization. All of them were applied at different times (and also parallel) but none of them with substantial success. Yet, the Society of Jesus, did not grow tired of outlining their efforts and advances and asking for military protection and administrative support from the Manila government.

This article has advanced in three steps. In the first, the setting of the colonial system of the Philippines was presented and the special situation of the Jesuits was highlighted in the first half of the eighteenth century. Second, two booklets were analyzed, which stressed the specific value of the Jesuit missionaries for the natives in the frontier zones that were most prone to attacks from Muslim raiders. Starting from this analysis, finally, the third step consisted in emphasizing the image cultivation of the Jesuits in the Philippines, in the light of growing criticism of the Society of Jesus by enlightened thinkers and rulers all over the globe.

In conclusion, it could be observed that the propagandistic "machinery" of the Jesuits, including their printing press in Manila, was well aware of the growing unease of the global Catholic society with their work. Hence, it can be assumed that their publications were not only aimed at the natives, to defend their villages, and at the colonial government, to support their fight against the raiders with more means, but they were also meant to meet the necessities of their order on a higher level. The texts probably intended to underline the usefulness of their work for the Spanish government, as guarantor of the frontiers of their colonies, be it as missionaries or even as commanders of military units, fighting the "infidels." Thereby, the texts might have contributed to attenuate the anti-Jesuit attitudes. In the end, however, all of these local efforts were in vain against the global currents. The Jesuits were disbanded, its members were expelled from the Philippines, and their residences were mostly given to the Recollect order, their biggest competitor in the region. 